\title{
Mineral binding material with the use of paper manufacturing wastes
}

\author{
L.P. Chernyak ${ }^{1}$ (ORCID 000-0001-8479-0545), P.G. Varshavets ${ }^{2}$ (0000-0001-6324-0616), \\ N.O. Dorogan ${ }^{1}(0000-0002-4304-1297)$, O.M. Shnyruk ${ }^{1}$ \\ ${ }^{1}$ National Technical University of Ukraine "Igor Sikorsky Kyiv Polytechnic Institute”, av. Peremogy, 37, Bldg. 21, \\ Kyiv, 03056, Ukraine \\ Tel.: +380672985775 \\ E-mail:lpchernyak@ukr.net,nataliyadorogan@ukr.net,Shnyruk@gmail.com \\ ${ }^{2}$ «Fasad»LTD, 1-B Krainia st., Kyiv, 02660, Ukraine \\ Tel: +380503855277 \\ E-mail: p.varshavets@ukr.net
}

Article info: received 12.07.2019, revised 15.08.2019, accepted 30.08.2019

Chernyak, L.P., Varshavets, P.G., Dorogan, N.O., Shnyruk, O.M. (2019) Mineral binding material with the use of paper manufacturing wastes 3(44), doi: 10.26909/csl.3.2019.2

The possibility of making of mineral astringent material of the low temperature burning at utilization of wastes of production of paper - scope is shown. The analysis of compositions of raw material mixtures on the basis of the system chalk - clay - scope is conducted with varying of concentration of scope at the set descriptions of product of burning. The compositions of mixtures with introduction of 25 - $51 \%$ scope is determinated. The features of phase composition and indexes of properties for mineral astringent with the use of scope as technogenic raw material are shown at the maximal temperature $1100^{\circ} \mathrm{C}$ of burning.

Industrial use of multi-tonnage waste of various industries, including scopes from paper production, allows to solve complex issues of technology of production of silicate materials, resource conservation and ecology.

The feasibility of using scopes as man-made raw materials in the technology of mineral binders is determined by the peculiarities of the chemical and mineralogical composition - the presence of a complete complex of oxides necessary for the formation of a given phase composition during firing and the possibility of intensification of the sintering increase in the reactivity of the silicate system at.

The efficiency of practical use of an osprey on the basis of the above developments is defined as the prospect of increasing the volume of utilization of industrial waste, as well as obtaining a new kind of mineral binder material in the low-temperature firing, which differs from romance with improved strength indicators.

Key words: mineral astringent, scope, mixture raw material, composition, burning, phases composition, properties.

\section{Мінеральний в'яжучий матеріал із використанням відходів паперового виробництва}

\author{
Л.П. Черняк ${ }^{1}$, П.Г. Варшавець ${ }^{2}$, Н.О. Дорогань ${ }^{1}$ О.М. Шнирук ${ }^{1}$ \\ ${ }^{1}$ Національний технічний університет Украӥни “Київський політехнічний інститут”, \\ Київ, Україна \\ ${ }^{2}$ ТОВ «Фасад», Київ, Україна
}

В статті показано можливість виготовлення мінерального в'яжучого матеріалу низькотемпературного випалу при використанні відходів виробництва паперу - скопу. Проведено аналіз складів сировинних сумішей на основі системи крейда - глина - скоп з варіюванням концентрації скопу при заданих характеристиках продукту випалу. Визначено склади сумішей з введенням 25 - 51 мас. \% скопу. Показано особливості фазового складу та показників властивостей отриманого мінерального в'яжучого з використанням скопу як техногенної сировини при максимальній температурі випалу $1100{ }^{\circ} \mathrm{C}$. 


\section{Вступ}

Розширення сировинної бази виробництва силікатних матеріалів із застосуванням відходів інших галузей промисловості є актуальною задачею, що комплексно вирішує питання хімічної технології, ресурсозбереження та охорони довкілля $[1,2]$. У значному ступені це стосується ресурсоємного виробництва мінеральних в'яжучих матеріалів [3].

Відомо, що виробництво паперу супроводжується утворенням багатотоннажних відходів, серед яких значну частку складає скоп $[4,5]$. Скоп являє собою суміш целюлозних волокон, дисперсних органічних і неорганічних речовин. Хімікомінералогічний склад і теплотворна здатність скопу визначили напрямки досліджень і розробок з його утилізації в енергетичному та агропромисловому комплексах, для виготовлення будівельних матеріалів [6 - 10]. При цьому щодо будівельних матеріалів запропоновано використання скопу як наповнювача при виготовленні тепло- і звукоізоляційних плит та як сировинний компонент маси для виготовлення керамзиту і аглопориту - спучених гранульованих керамічних матеріалів, що отримують шляхом випалу при температурі $\geq 1150^{\circ} \mathrm{C}$. Проте фактичні обсяги утилізації скопу не відповідають кількісному рівню утворення та накопичення цих відходів промисловості.

\section{Мета роботи}

Подана робота присвячена розвитку технологічних засад використання скопу як техногенної сировини для виготовлення в'яжучого матеріалу низькотемпературного випалу. При цьому ставиться на меті максимально можлива утилізація скопу в масоємному виробництві мінеральних в'яжучих.

\section{Матеріали та методи дослідження}

Об’єктом дослідження стали сировинні суміші для виготовлення в'яжучого матеріалу на основі силікатної системи крейда - глина - відходи промисловості. При цьому були застосовані:

- мергель Межигірсько-Дубовецького родовища Івано-Франківської обл.;

- крейду Здолбунівського родовища Рівненсьської обл.;

- глину спондилову Озерянського родовища Київської обл.;

- скоп - відходи виробництва паперу ПрАТ «Київський картонно-паперовий комбінат» [11].

За хімічним складом досліджувані проби відзначаються підвищеним вмістом $\mathrm{CaO}$, утворюючи ряд: крейда $>$ мергель $>$ скоп > глина (табл.1).

При цьому має місце суттєва різниця у кількісному співвідношенні оксидів:

- $\mathrm{CaO}: \mathrm{SiO}_{2}$ крейда > мергель > скоп > глина,

- CaO: $\mathrm{Al}_{2} \mathrm{O}_{3}$ крейда > мергель > скоп > глина.

Спондилова глина характеризується відносно більшим вмістом $\mathrm{Fe}_{2} \mathrm{O}_{3}$ та лужних оксидів.

\section{Результати та їх обговорення}

Аналіз мінералогічного складу досліджуваної сировини показав (рис. 1, 2):

- мергель характеризується превалюючим вмістом кальциту (73,3 мас. \%) поряд з каолінітом (14,3 мас. \%), кварцом (10,0 мас. \%), доломітом (3,1 мас. \%) та гетитом (1,9 мас. \%);

- основним породоутворюючим мінералом здолбунівської крейди є кальцит (97,6 мас. \%) с домішками доломіту (1,2 мас. \%), кварцу та каолініту - відповідно 0,5 и 0,6 мас. \%;

Таблиця 1.

Хімічний склад сировини

\begin{tabular}{|l|c|c|c|c|c|c|c|c|c|c|}
\hline \multirow{2}{*}{$\begin{array}{c}\text { Назва } \\
\text { проби }\end{array}$} & \multicolumn{70}{|c|}{ Вміст оксидів, мас. \% } \\
\cline { 2 - 14 } & $\mathrm{SiO}_{2}$ & $\mathrm{Al}_{2} \mathrm{O}_{3}$ & $\mathrm{Fe}_{2} \mathrm{O}_{3}$ & $\mathrm{TiO}_{2}$ & $\mathrm{CaO}$ & $\mathrm{MgO}$ & $\mathrm{SO}_{3}$ & $\mathrm{Na}_{2} \mathrm{O}$ & $\mathrm{K}_{2} \mathrm{O}$ & в.п.п \\
\hline мергель & 16,70 & 5,67 & 1,71 & - & 42,13 & 0,68 & 0,17 & - & - & 33,21 \\
\hline крейда & 0,77 & 0,25 & 0,13 & - & 55,0 & 0,25 & 0,08 & - & - & 43,49 \\
\hline спондилова & 51,05 & 8,89 & 3,21 & 0,60 & 15,42 & 2,00 & 0,50 & 0,22 & 2,21 & 15,90 \\
\hline скоп & 10,23 & 7,80 & 0,56 & 0,27 & 25,77 & 1,27 & 0,20 & 0,33 & 0,17 & 50,41 \\
\hline
\end{tabular}


- спондилова глина відноситься до групи полімінеральних, відзначається підвищеним вмістом кальциту (21 мас. \%), гідрослюди (20 мас. \%) та кварцу (35 мас. \%);

- скоп характеризується розвитком кристалічних фаз кальциту, каолініту, кварцу із включеннями польового шпату.
В роботі використовували сполучення сучасних фізико-хімічних методів аналізу із стандартизованими тестуваннями властивостей сировини та в'яжучих речовин [12 - 14].

Рентгенофазовий аналіз (порошкові препарати) за допомогою дифрактометру ДРОН-3М (випромінювання $\mathrm{Cu} \mathrm{K \alpha} 1$ - 2, напруга $40 \mathrm{kV}$, струм 20 mA, швидкість 2 град/хв.).

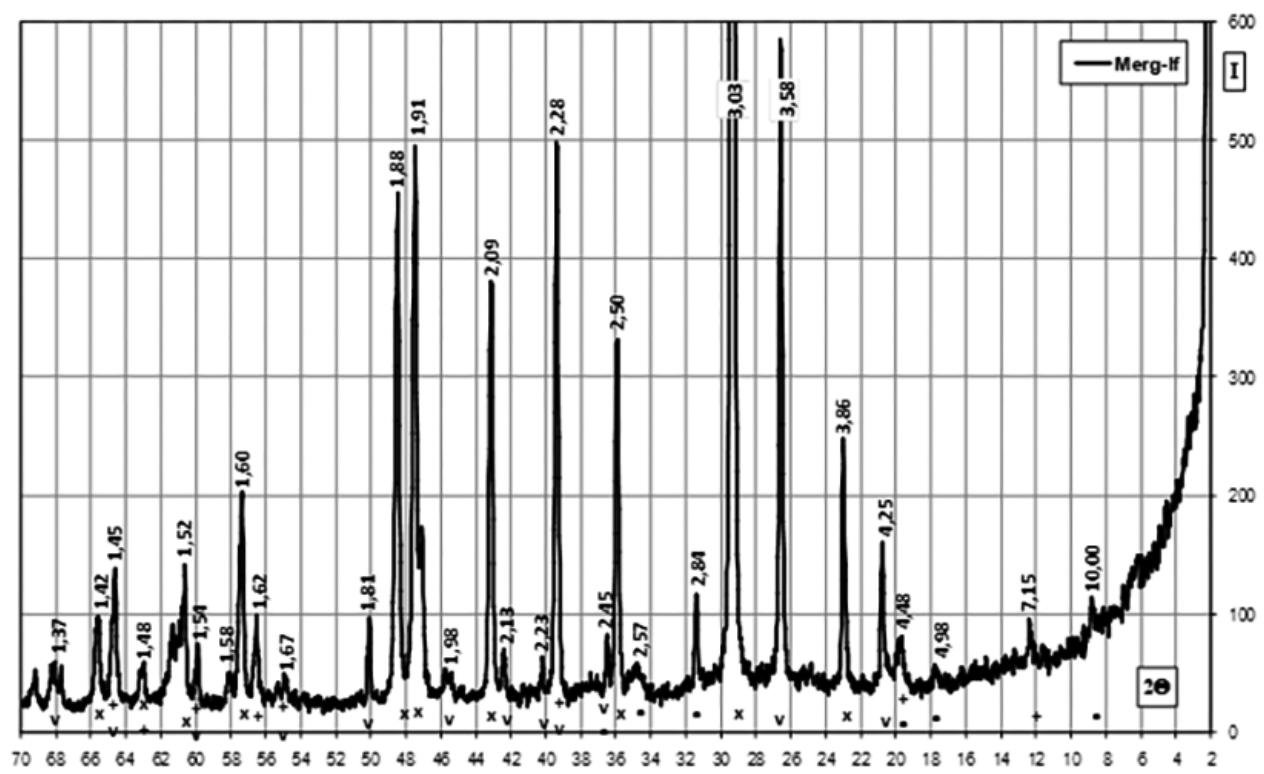

Рис. 1. Дифрактограма проби мергелю

Позначення: v - кварц, + - каолініт, $\mathrm{x}$ - кальцит, $\bullet-$ гідрослюда

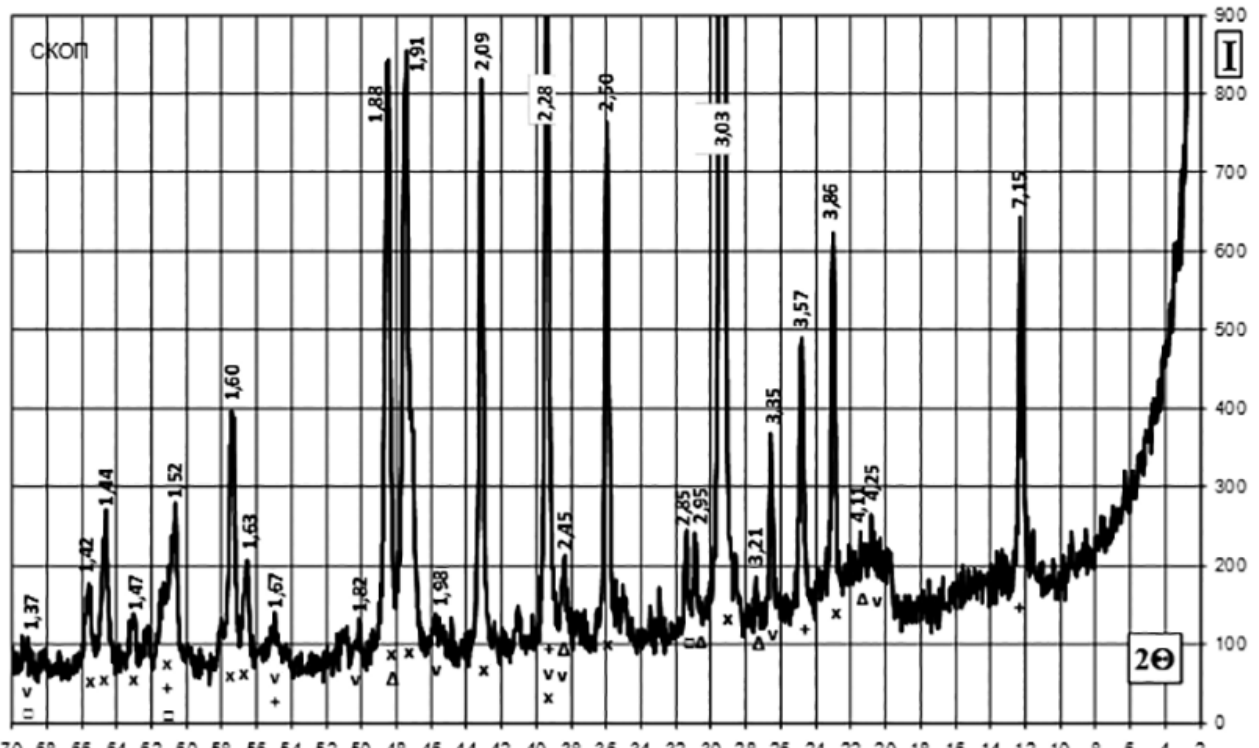

Рис. 2. Дифрактограма проби скопу

Позначення: + - каолініт, $\mathrm{x}$ - кальцит, $\mathrm{v}$ - кварц, $\Delta$ - польовий шпат 
Відповідно до сучасної технології в'яжучих сировинні суміші визначеного складу готували шляхом дозування компонентів по масі, змішування та гомогенізації при помелі у кульовому млині, випалу і помелу кінцевого продукту.

Всі зразки дослідних сумішей, показники яких порівнювали, сушили та випалювали разом, аби виключити можливість різниці в ступеню термічної обробки.

Склад і властивості в'яжучого матеріалу. Для визначення можливих обсягів утилізації скопу в технології в'яжучих матеріалів низькотемпературного випалу типу романцементу було проведено аналіз складів вихідних сировинних сумішей із застосуванням комп’ютерної програми «РоманЦем» [15]. При цьому склад вихідних сировинних сумішей визначали у відповідності з відомими рекомендаціями щодо технології романцементу в інтервалі заданих значень гідравлічного модулю НМ = 1,1 - 1,7.

Аналіз отриманих результатів показав, що у вказаному інтервалі НМ можлива концентрація скопу у складі сировинних сумішей суттєво залежить від кількісного співвідношення інших компонентів.

Встановлено, що у трикомпонентній суміші на основі системи крейда - глина спондилова - скоп можливий вміст останнього становить при $\mathrm{HM}=1,7$ від 12,0 до 64,0 мас. \%, при $\mathrm{HM}=1,1$ від 6,0 до 88,0 мас. $\%$ (рис 3, 4).

3 погляду на досягнення необхідних в'яжучих властивостей при визначенні досліджуваних сировинних сумішей дотримувались визнаних рекомендацій щодо значень кремнеземного і глиноземного модулів [16]. При цьому очевидно, що рекомендовані значення кремнеземного модулю в'яжучого $(\mathrm{n}=1,9-3,0)$ досягаються при вмісті скопу 30 - 75 мас. \% для $\mathrm{HM}=1,1$ та 25 - 51 мас. \% для $\mathrm{HM}=1,7$.

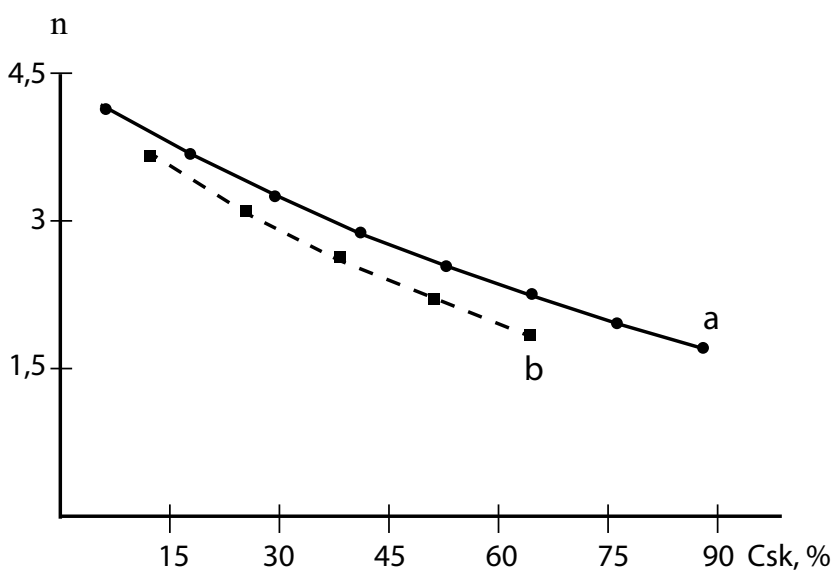

Рис. 3. Залежність кремнеземного модулю n від концентрації скопу (Csk) в суміші на основі крейди і глини спондилової при НМ = 1,1 (a) і НM=1,7 (b)
Обрані для подальшого дослідження суміші на основі мергелю та системи крейда - глина спондилова - скоп характеризуються відмінностями кількісного співвідношення компонентів і хімічного складу (табл. 2, 3).

Так, суміш S30 з 25 мас. \% скопу характеризується кількісним співвідношенням крейда : глина : скоп $=2: 1: 1$, а для суміші S32 з 51 мас. \% скопу аналогічне співвідношення становить 2,3 : $1: 3,4$.

За хімічним складом суміші S30, S32 із скопом суттєво відрізняються від 1m 3 мергелю меншим вмістом $\mathrm{CaO}$ (34,6 - 37,9 проти 42,1 мас. \%) і $\mathrm{Fe}_{2} \mathrm{O}_{3}$ (0,8 - 1,1 проти 1,7 мас. \%) при більшому вмісті $\operatorname{MgO}(1,0$ - 1,1 проти 0,7 мас. \%).

Після випалу хімічний склад досліджуваних проб мінерального в'яжучого має при гідравлічному модулі $\mathrm{HM}=1,7$ забезпечити рекомендовані для цементу значення кремнеземного модулю $\mathrm{n}=2,2$ - 3,1 (табл. 4).

Результати рентгенофазового аналізу вказують на відмінності у фізико-хімічних перетвореннях при випалі дослідних сумішей, що корелюються із вказаним хімічним складом і залежать від вмісту в них скопу та співвідношення компонентів (рис. 5, 6).

Очевидно, що після випалу на $1100{ }^{\circ} \mathrm{C}$ при однаковому розвитку кристалічних фаз силікатів кальцію типу CS i $\mathrm{C}_{2} \mathrm{~S}$ проба S32 з використанням скопу відрізняється від 1m з мергелю:

- щодо кристалічних фаз алюмінатів кальцію інтенсифікацією утворення майєніту $\mathrm{C}_{12} \mathrm{~A}_{7}$ $(4,90 \AA)$ при майже однаковому вмісті $\mathrm{C}_{3} \mathrm{~A}$ (2,70 А) та СА $(2,52 \AA)$;

- щодо кристалічних фаз алюмосилікатів кальцію - зменшенням утворень геленіту $\mathrm{C}_{2} \mathrm{AS}(2,86 \AA)$;

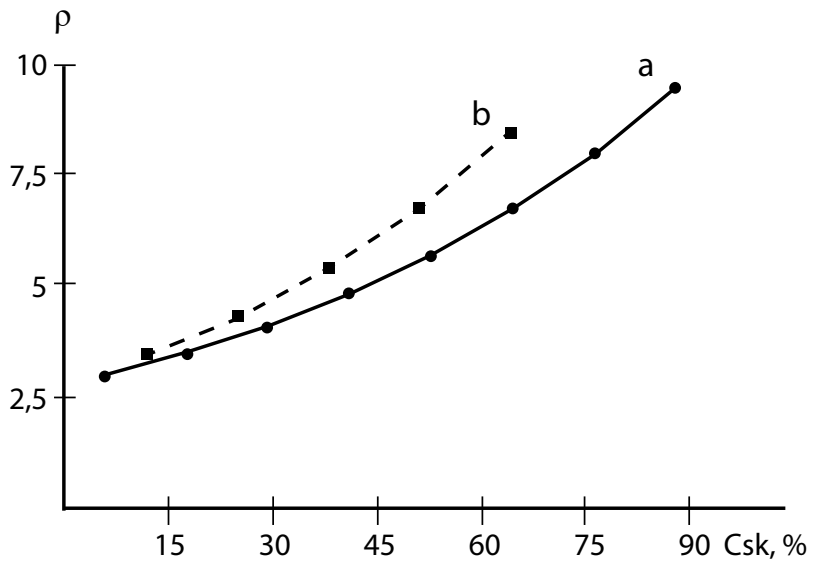

Рис. 4. Залежність глиноземного модулю р від концентрації скопу (Csk) в суміші на основі крейди і глини спондилової при НM = 1,1 (a) і НM = 1,7 (b) 
- щодо залізовмісних кристалічних фаз меншим утворенням $\mathrm{C}_{4} \mathrm{AF}(2,63 \AA)$;

- щодо кристалічних фаз магнезіальних силікатів кальцію - утворенням окерманіту $\mathrm{C}_{2} \mathrm{MS}_{2}(2,86 \AA)$;

- суттєво меншою кількістю $\mathrm{CaO}$ (1,69 і 2,38 А̊) при більшому вмісті кристалічного $\mathrm{SiO}_{2}(3,35 \AA)$.
Отримані результати тестувань проб досліджуваних матеріалів після випалу з максимальною температурою $1100^{\circ} \mathrm{C}$ свідчать про певні відмінності їх в’яжучих властивостей (табл. 5).

Згідно класифікації ДСТУ Б В.27-91-99 [16] за швидкістю тужавлення проби в'яжучого $1 \mathrm{~m} 3$ мергелю і S30 - S32 на основі системи крейда - глина скоп відносяться до групи швидкотужавіючих (тер-

Таблиця 2.

Склади сировинних сумішей

\begin{tabular}{|c|c|c|c|c|}
\hline \multirow{2}{*}{$\begin{array}{c}\text { Код } \\
\text { суміші }\end{array}$} & мергель & врейда & глина спондилова & скоп \\
\cline { 2 - 5 } & 100 & - & - & - \\
\hline 1m & - & 50,0 & 25,0 & 25,0 \\
\hline S30 & - & 34,0 & 15,0 & 51,0 \\
\hline
\end{tabular}

Таблиця 3.

Хімічний склад сировинних сумішей

\begin{tabular}{|c|c|c|c|c|c|c|c|}
\hline \multirow{2}{*}{$\begin{array}{c}\text { Код } \\
\text { суміші }\end{array}$} & \multicolumn{7}{|c|}{ Вміст оксидів, мас.\% } \\
\cline { 2 - 20 } & $\mathrm{SiO}_{2}$ & $\mathrm{Al}_{2} \mathrm{O}_{3}$ & $\mathrm{Fe}_{2} \mathrm{O}_{3}$ & $\mathrm{CaO}$ & $\mathrm{MgO}$ & $\mathrm{SO}_{3}$ & В.п.п \\
\hline $1 \mathrm{~m}$ & 16,70 & 5,67 & 1,71 & 42,13 & 0,68 & 0,17 & 33,21 \\
\hline $\mathrm{S} 30$ & 16,82 & 4,43 & 1,05 & 37,91 & 0,96 & 0,49 & 38,34 \\
\hline $\mathrm{S} 32$ & 13,92 & 5,58 & 0,84 & 34,57 & 1,07 & 0,49 & 43,53 \\
\hline
\end{tabular}

Таблиця 4.

Хімічний склад в’яжучого матеріалу

\begin{tabular}{|c|c|c|c|c|c|}
\hline \multirow{2}{*}{ Код суміші } & \multicolumn{5}{|c|}{ Вміст оксидів, мас. \% } \\
\cline { 2 - 7 } & $\mathrm{CaO}$ & $\mathrm{SiO}_{2}$ & $\mathrm{Al}_{2} \mathrm{O}_{3}$ & $\mathrm{Fe}_{2} \mathrm{O}_{3}$ & $\mathrm{MgO}^{*}$ \\
\hline $1 \mathrm{~m}$ & 62,82 & 24,90 & 8,46 & 2,55 & 1,01 \\
\hline $\mathrm{S} 30$ & 61,48 & 27,28 & 7,18 & 1,71 & 1,56 \\
\hline $\mathrm{S} 32$ & 61,22 & 24,65 & 9,88 & 1,49 & 1,89 \\
\hline
\end{tabular}

Таблиця 5.

Властивості в’яжучого матеріалу

\begin{tabular}{|c|c|c|c|c|c|}
\hline \multirow{2}{*}{\multicolumn{2}{|c|}{ Показники }} & \multicolumn{4}{|c|}{ Код проби } \\
\hline & & $1 \mathrm{~m}$ & $\mathrm{~S} 30$ & S31 & S32 \\
\hline \multicolumn{2}{|c|}{ Тонкість помелу, залишок на ситі 008, мас. \% } & 8 & 7 & 8 & 8 \\
\hline \multirow{2}{*}{$\begin{array}{c}\text { Терміни } \\
\text { тужавлення, хв. }\end{array}$} & початок & 15 & 25 & 30 & 35 \\
\hline & кінець & 45 & 70 & 85 & 90 \\
\hline \multicolumn{2}{|c|}{ Міцність на стиск через 28 діб, МПа } & 18 & 22 & 22 & 23 \\
\hline
\end{tabular}




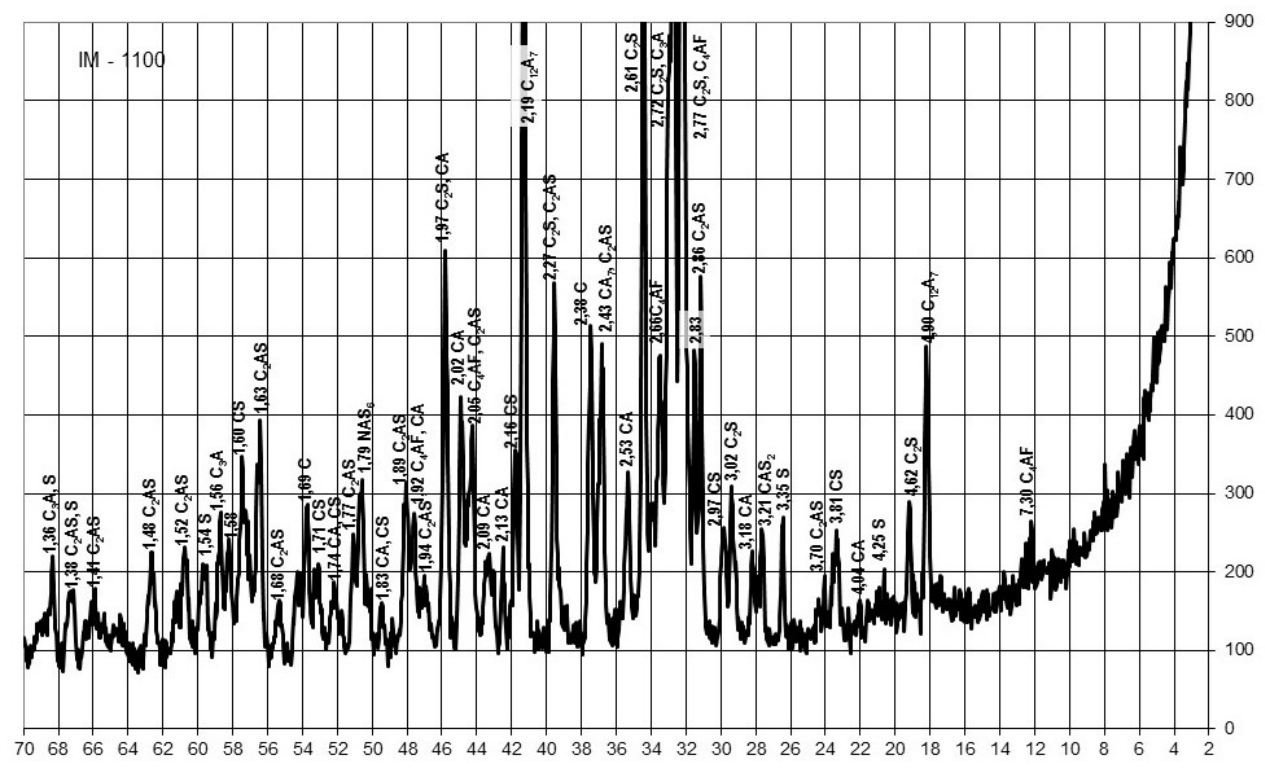

Рис. 5. Дифрактограма проби $1 \mathrm{~m}$ після випалу на $1100{ }^{\circ} \mathrm{C}$

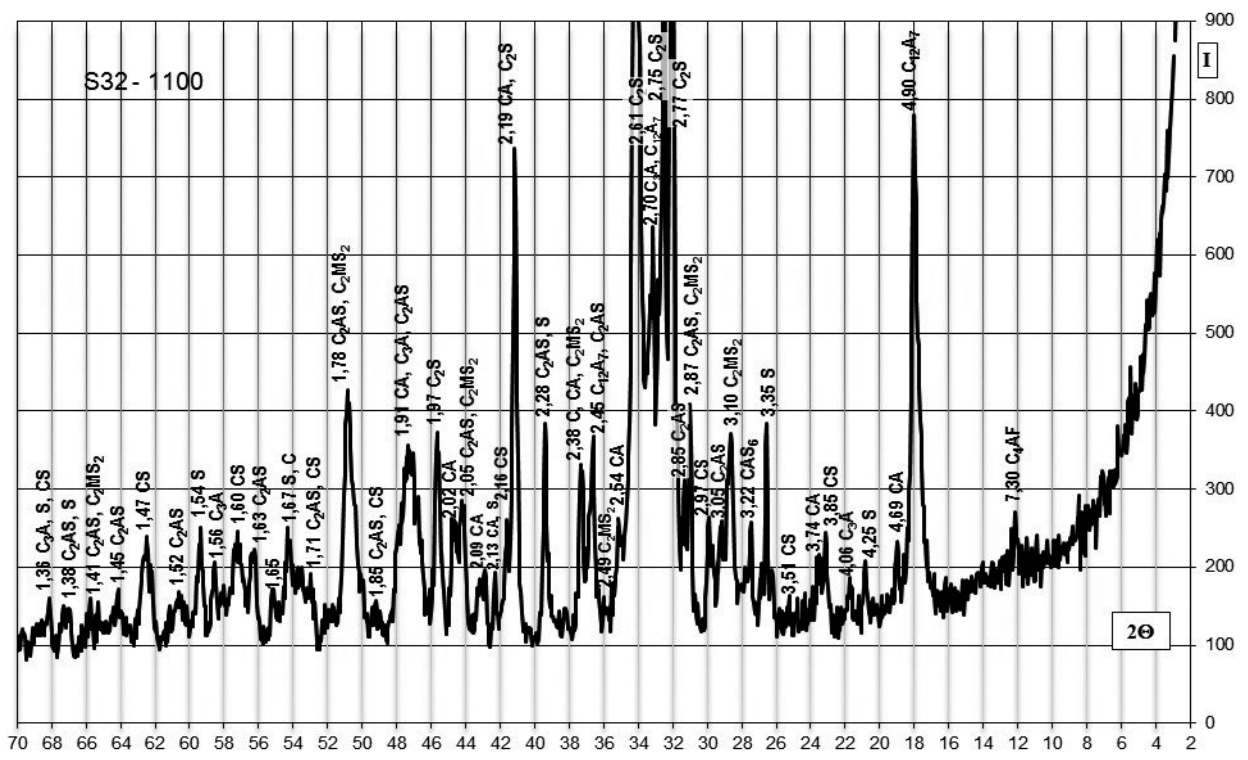

Рис. 6. Дифрактограма проби S32 після випалу на $1100{ }^{\circ} \mathrm{C}$

мін початку від 15 хв. до 45 хв.), характерними представниками якої вважаються ангідритовий та глиноземистий цемент. При цьому очевидно, що із збільшенням концентрації скопу у досліджуваних сумішах має місце уповільнення процесу тужавлення, що у найбільшому ступені проявляється у випадку проби S32.

Такі гідравлічні мінеральні в'яжучі низькотемпературного випалу можуть стати в ряді будівельних робіт замінником більш енергоємного і вартісного портландцементу $[17,18]$.

\section{Висновки}

1. Промислове використання багатотоннажних відходів різних галузей господарства, в тому числі скопу від виробництва паперу, дозволяє комплексно вирішувати питання технології виробництва силікатних матеріалів, ресурсозбереження і екології.

2. Доцільність використання скопу як техногенної сировини в технології мінеральних в'яжучих матеріалів визначається особливостями хіміко-мінералогічного складу - наявністю повного комп- 
лексу оксидів, необхідних для утворення при випалі заданого фазового складу та можливістю інтенсифікації спікання збільшення реакційної здатності силікатної системи.

3. Ефективність практичного використання скопу на основі наведених розробок визначається як перспективою збільшення обсягів утилізації відходів промисловості, так і отриманням при низькотемпературному випалі нового різновиду мінерального в'яжучого матеріалу, що відрізняється від романцементу поліпшеними показниками міцності.

\section{References}

1. Комплексное развитие сырьевой базы промышленности строительных материалов / И.Б. Удачкин, А.А. Пащенко, Л.П. Черняк и др. - К. : Будівельник. - 1988. - 104 с.

2. Моссур, П.М. Техногенное минеральное сырье и его использование в Украине / П.М. Моссур, С.В. Негода // ГИАБ. - 2007. - № 6. - С. 299 - 307.

3. Пащценко, А.А. Энергосберегающие и безотходные технологии получения вяжущих веществ / А.А. Пащенко, Е.А. Мясникова, Е.Р. Евсютин. - К.: Вища шк. - 1990. - 223 с.

4. Monte, M.C. Waste management from pulp and paper production in the European Union / M.C.Monte, E.Fuente, A.Blanco, C.Negro // Waste Management. 2009. - Vol. 29, Is. 1. - P. 293 - 308.

5. Simao, L. Wastes from pulp and paper mills - a review of generation and recycling alternatives / L. Simao, D. Hotza, F. Raupp-Pereira, J. A. Labrincha, 0. R. K. Montedo // Cerâmica. - 2018. - Vol. 64. - No. 371. - P. 443 - 453.

6. Gopal, $M$. The scope for utilizing jute wastes as raw materials in various industries: A review / Agricultural Wastes. - 1986. - Vol. 15. - Is. 2. - P. 149 - 158.

7. Кирсанов, А.С. Утилизация отходов бумажной промышленности в производстве гранулированных теплоизоляционных материалов: автореф. дис. на соискание научн. степени канд. техн. наук: спец. 03.00.16 «Экология» / А.С. Кирсанов. - Пенза. 2002. $-20 \mathrm{c}$.

8. Баталии, Б., Козлов, И. Строительные материалы на основе скопа - отхода целлюлозно-бумажной промышленности // Строительные материалы. 2004. - №1. - С. 42 - 43.

9. Ширинкина, Е. С., Айтжанова, У. М. Переработка скопа, образующегося в технологическом процессе картонно-бумажного производства // European science № 2(12). - 2016. - С. 13 - 16.

10. Мифтахов, М.Н. Перспективы утилизации скопа - отхода картонно-бумажного производства / Уфа: Изд-во: ООО «Агентство международных исследований». - 2015. - № 6 - 1. - С. 26 - 27.

11. Тахтуев, Б. Г. Переработка отходов картоннобумажных произодств / Тезисы 2-й Международной конференции «Сотрудничество для решения проблемы отходов». - Харьков. - 2005. - С. 224.

12. Горшков, В.С. Методы физико-химического анализа вяжущих веществ / В.С. Горшков, В.В. Тимашев, В.Г. Савельев // М.: Высшая школа. 1981. $-334 \mathrm{c}$.

13. Хімічна технологія тугоплавких неметалевих i силікатних матеріалів у прикладах і задачах: навч. посібник у 2-х ч. Ч.1. Технологічні розрахунки в хімічних технологіях тугоплавких неметалевих i силікатних / [Брагіна Л.Л., Корогодська А.М., Пітак О.Я. та ін.]; за ред. М.І. Рищенка. - Х.: Підручник НТУ «ХПИ». - 2012. - 332 c.

14. Taylor, W. Purves. Practical Cement Testing / W. Purves Taylor// London: Forgotten Books. -2017. - 334 p.

15. Свідерський, В.A. Програмне забезпечення технології низько температурних в'яжучих матеріалів / В.А. Свідерський, Л.П.Черняк, О.В. Сангінова, Н.О. Дорогань, М.Ю. Цибенко // Строительные материалы и изделия. - К. - 2017. - № 1 - 2 (93). C. $22-24$.

16. ДСТУ Б В.2.7-91-99. В'яжучі мінеральні. Класифікація. - Введ. 01.03.1999. - К.: Держбуд України. - 1999. - 26 с.

17. Miras, A. Natural cements for construction applications / A. Miras, T.Markopoulos, E. Galan // 27th Reunión de la Sociedad Española de Mineralogía. 2007. - p. 94.

18. Шельонг, Г. Романцемент - в'яжуче для опоряджувальних робіт в будівництві / Г. Шельонг, М.А. Саницький, Т.П. Кропивницька, Р.М. Котів // Строительные материалы и изделия. - К. - 2012. № 1 (72). - С. 7 - 12. 